OLIVERA ILIĆ

904:631.31"652"(497.11)

Institute of Archaeology,

COBISS.SR-ID 228045836

Belgrade, Serbia

o.ilic@ai.ac.rs

Original research article

Received: April $14^{\text {th }} 2016$

Accepted: June $20^{\text {th }} 2016$

\title{
FINDS OF ROMAN AGRICULTURAL TOOLS ON THE DANUBIAN LIMES IN UPPER MOESIA AS INDICATORS OF AGRICULTURAL DEVELOPMENT IN THE AREA OF MILITARY CAMPS
}

\begin{abstract}
This paper discusses the Roman agricultural tools on the fortresses along the Danubian limes in Upper Moesia. The agriculture played an important role among Roman soldiers. The development and improvement of tools used for cultivating grain, which can be established after analyses of archaeological material, influenced the intensity of agricultural production and increased quantities. At the same time, this indicates the importance of the Danubian limes in the production of grain as the basic food intended for the military stationed in numerous castella along the Danube.
\end{abstract}

KEYWORDS: AGRICULTURAL TOOLS, FORTRESSES ALONG THE DANUBIAN LIMES, LATE ROMAN PERIOD.

Agriculture was a basic activity of the Balkan inhabitants even before these territories were occupied and became part of the Roman Empire'. However, the new Roman reign brought new organisation methods, more or less successfully including the local population, which again depended on the Romanisation level of the newly established Roman provinces.

Due to the lack of historic data, the role of the autochthonous elements can only be assumed, but not completely determined. At the same time, the organisation of agricultural estates remains insufficiently defined, since the data given by Roman agronomists is mostly related to other parts of the Roman Empire. ${ }^{2}$ For example, in Apennine

1 The article results from the project: Viminacium, Roman city and military camp - research of the material and non material culture of inhabitants by using the modern technologies of remote detection, geophysics, GIS, digitalization and $3 D$ visualization (no 47018), funded by The Ministry of Education, Science and Technological Development of the Republic of Serbia.

2 The most data about Roman agriculture can be found in works of Roman agronomists: Cato et Varro, De agricultura; Plinius, Naturalis historia; Columella, De re rustica.
Peninsula, due to different socio-economic relationships, but also due to the climate and other natural circumstances, the organisation of agriculture must have been different from that in the Balkan provinces. As a result of this, archaeological finds, primarily agricultural tools, remain the best indicator of the agricultural activities in this area during Roman times.

According to their context, the agricultural tools excavated at the fortifications along the Danubian limes can mostly be dated into the Late Roman era. One can presume that the same, or very similar, types were used during the Principate, since these items belong to a group that rarely changes. In addition, the methods of agriculture remained somewhat unchanged during the entire Roman period. Much later, during the Middle Ages and through the entire 19th century, Serbian farmers used wooden ploughs, sickles and scythes, similar to those from the Roman period.

Scarce data from Roman authors reveals that the greatest part of Upper Moesia was covered with woods, including the area of the Danubian 
limes. Priscus writes about thick woods to the north of Niš (Priscus, Frg. 8, p.291, 23-26). The forest was thick and impenetrable from the Danube at Branicevo to Trajan table. This appearance was retained for a long time. It could assume that the Byzantine Empire in the Middle Ages, better protected from the enemy by the impassability of roads than the troops. In a much later period, in $19^{\text {th }}$ century travel writers spoke about thick oak forests in the territory of today's Serbia (Opra 1998: 169-170). It was well justified that the natural features of Serbia remained unchanged since the Roman times. Extensive changes of the natural surroundings occurred later, with the greater influences of the industrial revolution reaching our territory somewhat later than Western Europe.

A very important process in agricultural development is clearing forests and obtaining cultivable soil. Although there is no data preserved regarding organised clearing of great forest areas, it is certain that, during Antiquity, these activities took place on a large scale, especially in those areas suitable for farming. As a consequence of this, in areas of Roman provinces in the territory of modern Serbia, and along the Danubian limes, a great number of tools have been discovered, which were used for clearing, mostly forest vegetation, in order to obtain cultivable soil (И. Поповић 1988).

In fortifications, mostly of the Late Roman times, tools used for tilling soil were discovered in large quantities, indicating the changes that took place in this period, related to supplying troops. Most of the agricultural tools coming from military camps represent single finds, although hoards were also discovered, like those from the castra of Boljetin or Saldum. Among the finds of Roman tools, special attention will be paid to those intended for ploughing and sowing grain.

\section{Ploughshare}

At the sites along the Danubian limes in Upper Moesia, there were numerous ploughshare finds, representing parts of ploughs (Fig. 1). According to the typology by I. Popović, they are divided into several types and variants (И. Поповић 1988: 98-104). The majority belong to symmetrical forms, while a single non-symmetrical example comes from the castrum of Karataš (Diana). The symmetrical ploughshare type was discovered in layers or hoards and is mostly dated into Late antiquity, actually the second half of the $4^{\text {th }}$ century. The find of a non-symmetrical example reveals that during Late antiquity, beside ploughshares, also contemporary ploughing devices, ploughs, were used.

Type $A a$ is a symmetrical ploughshare with a triangular blade and a very sharp point, spearshaped, discovered on the following sites:

\section{Karataš (Diana)}

Excavation in 1983, C/923

End of the $4^{\text {th }}$ and the beginning of the 5th century Length: $32 \mathrm{~cm}$.

Bibliography: И. Поповић, Античко оруђе, type XXIII Aa, 100, cat. 1.

\section{Kostol (Pontes)}

Excavation in 1982, C/212

$4^{\text {th }}$ century

Length: $34.5 \mathrm{~cm}$.

Bibliography: И. Поповић, Античко оруђе, type XXIII Aa, 101, cat. 2.

\section{Saldum}

Excavation in 1968, field inv. 266

Tool hoard, $4^{\text {th }}$ century

Length: $40 \mathrm{~cm}$.

Bibliography: И. Поповић, Античко оруђе, type XXIII Aa, 101, cat. 3; G. Jeremić, Saldvm, 164, cat. 484 . 
ப

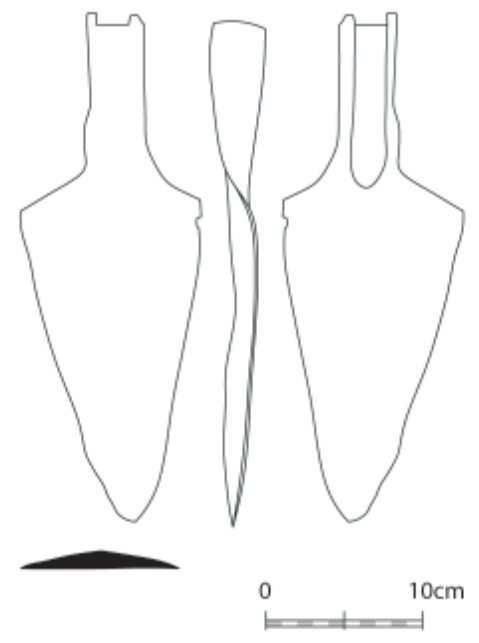

2.

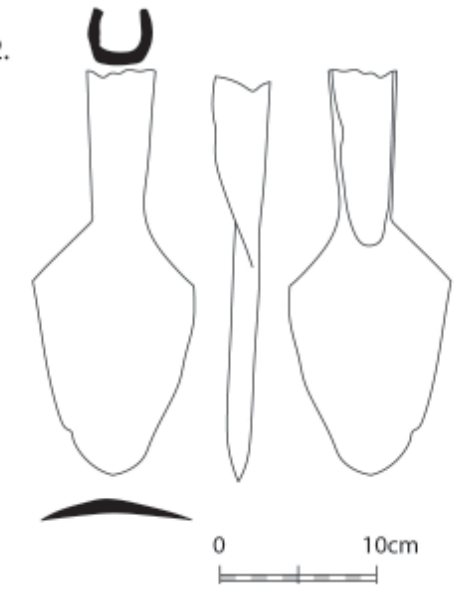

4.
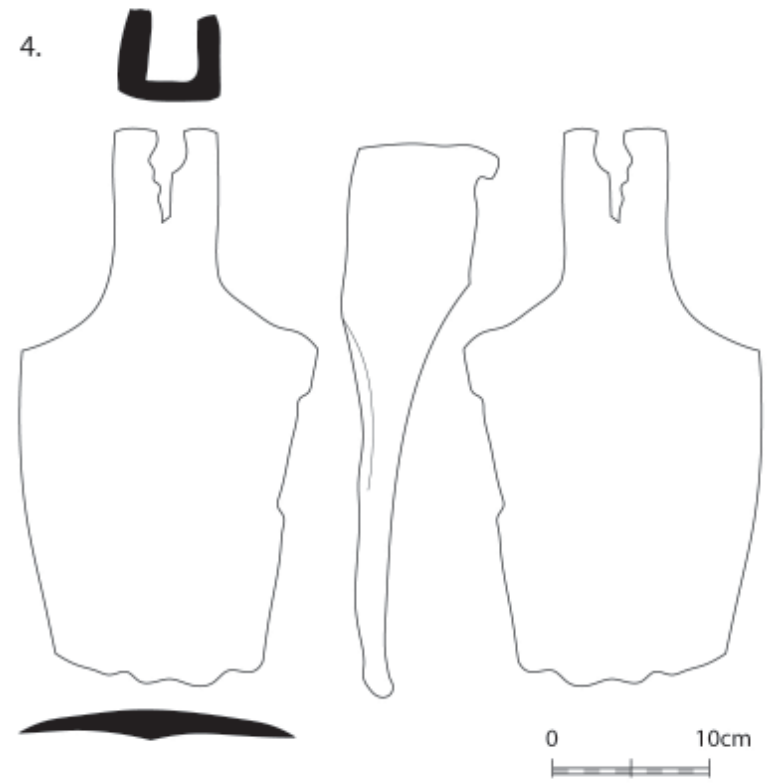

5.
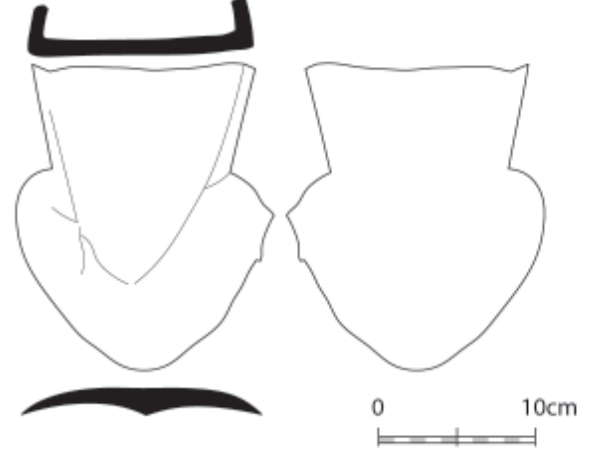

3.

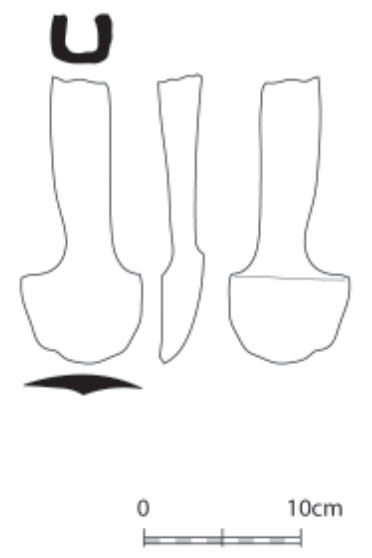

6. U

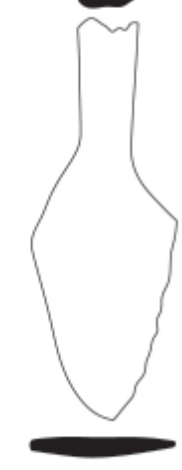

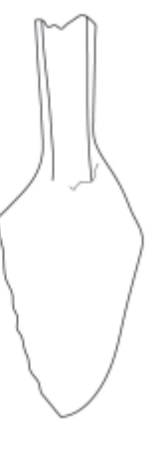

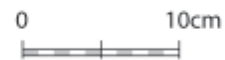

7

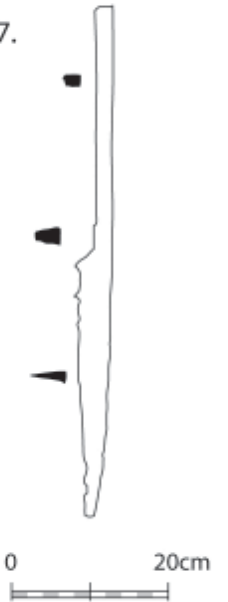

Fig. 1 Different types of ploughshares and coulter from the sites at the Danubian limes: 1, 6. ploughshares Karataš/ Diana; 2-3. ploughshares, Boljetin/Smorna (tool hoard); 4. ploughshare Kostol/Pontes; 5. ploughshare, Dražaj near Grocka (tool hoard); 7. coulter Boljetin/Smorna. 
Boljetin (Smorna)

Excavation in 1965, field inv. 81

$4^{\text {th }}$ century

Length: $31 \mathrm{~cm}$.

Bibliography: И. Поповић, Античко оруђе, type

XXIII Aa, 101, cat. 4.

\section{Boljetin (Smorna)}

Excavation in 1968, field inv. 864

Tool hoard discovered in an amphora, $4^{\text {th }}$ century

Length: $42 \mathrm{~cm}$.

Bibliography: Lj. Zotović, Starinar XXXIII-XXX-

IV, 221; И. Поповић, Античко оруђе, type XXIII

Aa, 101, cat. 5 .

Boljetin (Smorna)

Excavation in 1968, field inv. 864

Tool hoard discovered in an amphora, $4^{\text {th }}$ century Length: $35 \mathrm{~cm}$.

Bibliography: Lj. Zotović, Starinar XXXIII-XXXIV, 221; И. Поповић, Античко оруђе, type XXIII Aa, 101, cat. 6 .

Type $A b$ is a ploughshare with a triangular blade and a rounded point:

Boljetin (Smorna)

Excavation in 1966, field inv. 405

$4^{\text {th }}$ century

Length: $28 \mathrm{~cm}$.

Bibliography: Lj. Zotović, Starinar XXXIII-XXXIV, 221; И. Поповић, Античко оруђе, type XXIII $\mathrm{Ab}, 101$, cat. 2 .

Boljetin (Smorna)

Excavation in 1967, field inv. 760

Tool hoard, $4^{\text {th }}$ century

Length: $22 \mathrm{~cm}$.

Bibliography: Љ. Зотовић, Старинар XXXIIIXXXIV, 221; И. Поповић, Античко оруђе, type XXIII Ab, 101, cat. 3.
Boljetin (Smorna)

Excavation in 1967, field inv. 760

Tool hoard, $4^{\text {th }}$ century

Length: $28 \mathrm{~cm}$.

Bibliography: Љ. Зотовић, Старинар XXXIIIXXXIV, 221; И. Поповић, Античко оруђе, type XXIII Ab, 101, cat. 4.

Type Ad has a trapezoid shaped blade with rounded angles:

Kostol (Pontes)

Excavation in 1983, C/158

$4^{\text {th }}$ century

Length: $35.5 \mathrm{~cm}$.

Bibliography: И. Поповић, Античко оруђе, type XXIII Ad, 102, cat. 1.

Type $B$ possesses a symmetrical ploughshare with a triangular blade, with a more or less rounded point. On the Danubian limes, only two examples have been discovered so far:

Kostol (Pontes)

Excavation in 1932, C/271

$4^{\text {th }}$ to $6^{\text {th }}$ century

Length: $15.5 \mathrm{~cm}$.

Bibliography: И. Поповић, Античко оруђе, type XXIII B, 102, cat. 2.

Saldum

Excavation in 1968, field inv. 226

Tool hoard, $4^{\text {th }}$ century

Length: $20.5 \mathrm{~cm}$

Bibliography: И. Поповић, Античко оруђе, type XXIII B, 102, cat. 3; G. Jeremić, Saldvm, 164, cat. 486.

Type $E$ is the last variant of symmetrical ploughshares from the Danubian limes fortifications. Such a ploughshare is arrow-shaped, with a triangular blade: 
Ravna (Campsa)

Excavation in 1966, field inv. 96

$4^{\text {th }}$ century

Length: $73 \mathrm{~cm}$.

Bibliography: И. Поповић, Античко оруђе, type XXIII E, 103, cat. 1.

Saldum

Excavation in 1969, field inv. 559

$4^{\text {th }}$ century

Length: $64 \mathrm{~cm}$.

Bibliography: И. Поповић, Античко оруђе, type XXIII E, 103, cat. 2; G. Jeremić, Saldvm, 164, cat. 487.

\section{Kostol (Pontes)}

Excavation in 1980, C/102

$4^{\text {th }}$ to $6^{\text {th }}$ century

Length: $25 \mathrm{~cm}$.

Bibliography: И. Поповић, Античко оруђе, type XXIII E, 103, cat. 3.

Type $C$, according to typology by I. Popović, is described as a non-symmetrical ploughshare with a long, opened socket with a rectangular cross-section and a deltoid shaped blade. The only example was discovered at the site Karataš.

Karataš (Diana)

Excavation in 1981, C/384

$4^{\text {th }}$ century

Length: $26 \mathrm{~cm}$.

Bibliography: И. Поповић, Античко оруђе, type XXIII C, 102, cat. 1 .

The ploughshare types found at the Danubian limes fortifications were also discovered in the neighbouring territories of the Morava valley, Pannonia, Bulgaria, Hungary and Romania (Popović 1988: 103-104). We can say that the types named above represent typical features of the entire Balkans throughout the Roman era.

\section{Coulter}

A coulter is a heavy blade in the shape of a knife, fixed upon a joist, cutting vertically in front of the ploughshare, thus making ploughing easier. The majority of Roman coulters possessed a flat, dull side and were fixed onto the ploughshare joist. In the 3rd and 4th centuries, coulters were introduced with a loop on the dull side, used for fixing chains that were again used for fixing the coulters onto joists. According to the typology given by I. Popović, it is possible to distinguish two types of such a tool (И. Поповић 1988: 104-106). On the Danubian limes in Upper Moesia, both types were discovered in a hoard from Boljetin, dating from the 3 rd to the middle of the 5 th century.

Type A possesses a massive handle with a rectangular cross-section and a big flat or slightly bent, triangular blade. The dull side is flat, without a perforation or a loop used for fastening. Both types of this tool come from the castrum of Boljetin.

\section{Boljetin (Smorna)}

Excavation in 1967, field inv. 771

$4^{\text {th }}$ century

Length: $60 \mathrm{~cm}$.

Bibliography: И. Поповић, Античко оруђе, type XXIV A, 105, cat. 1.

\section{Boljetin (Smorna)}

Excavation in 1967, field inv. 760

Tool hoard, $4^{\text {th }}$ century

Length: $76.5 \mathrm{~cm}$.

Bibliography: Љ. Зотовић, Старинар XXXIIIXXXIV, 221; И. Поповић, Античко оруђе, type XXIV A, 105, cat. 2.

\section{Boljetin (Smorna)}

Excavation in 1967, field inv. 760

Tool hoard, $4^{\text {th }}$ century

Length: $57 \mathrm{~cm}$.

Bibliography: Љ. Зотовић, Старинар XXXIIIXXXIV, 221; И. Поповић, Античко оруђе, type XXIV A, 105, cat. 3. 
Type $B$ is a coulter which possesses a massive handle with a rectangular cross-section and a big, flat, triangular blade. On its dull side, at the point where the handle becomes the blade, there is a perforation or a loop, used for fastening.

Boljetin (Smorna)

Excavation in 1967, field inv. 76

Tool hoard, $4^{\text {th }}$ century

Length: $67.5 \mathrm{~cm}$.

Bibliography: Љ. Зотовић, Старинар XXXIII-

XXXIV, 221; И. Поповић, Античко оруђе, type XXIV B, 106, cat. 4.

\section{Cleaner hoe}

A cleaner hoe is a small shovel used for cleaning ploughshares. It consists of an oval or fanshaped blade. From Late Antiquity, there is a single find from the site of Kostol (Pontes). According to the typology by I. Popović, this find possesses features of type A, with an oval blade (Поповић 1988, 108). So far, this is the only find from the limes in Upper Moesia.

Kostol (Pontes)

Excavation in 1983, C/172

$4^{\text {th }}$ century

Length: $11 \mathrm{~cm}$.

Bibliography: И. Поповић, Античко оруђе, type XXVI A, 108, cat. 3.

\section{Hoe}

Throughout the entire Roman era, the hoe was a tool with a wide range of uses in agriculture. Apart from being used in gardens and vegetable gardens, this tool was used for cultivating grain. The lighter hoe type was used during grain and vegetable growth, in order to remove weeds and prevent soil from cracking. Light hoes were also used for digging up, manuring and covering seeds with soil. The basic type has not changed from Antiquity to modern times.

In the Danube valley, hoe finds are numerous. According to I. Popović, it is possible to distin- guish several basic hoe types, with sub-variants within each type (Поповић 1988: 39-44). Depending on the structure of the tilled soil, there are types with triangular, trapezoid or fan-shaped blades.

Hoe type $A a$ was discovered at several sites from the Danubian limes: in Čezava (Novae), Saldum and Karataš (Diana). This hoe type possesses a trapezoid shaped blade, with a round socket (Fig. 2).

Saldum

Excavation in 1968, field inv. 270

Tool hoard, $4^{\text {th }}$ century

Length: $24 \mathrm{~cm}$.

Bibliography: И. Поповић, Античко оруђе, type IV Aa, 40, cat. 11; G. Jeremić, Saldvm, 165, cat. 489.

Saldum

Excavation in 1968, field inv. 268

Tool hoard, $4^{\text {th }}$ century

Length: $30 \mathrm{~cm}$.

Bibliography: И. Поповић, Античко оруђе, type IV Aa, 40, cat. 12; G. Jeremić, Saldvm, 165, cat. 488.

Čezava (Novae)

Excavation in 1968, T/1119

$4^{\text {th }}$ century

Length: $15.6 \mathrm{~cm}$.

Bibliography: И. Поповић, Античко оруђе , type IV Aa, 40, cat. 16.

Variant $A b$ is distinguished by a trapezoid blade with rounded corners. Such examples were discovered within a tool hoard from the Boljetin castrum.

\section{Boljetin (Smorna)}

Tool hoard, $4^{\text {th }}$ century

Length: $11 \mathrm{~cm}$.

Bibliography: Љ. Зотовић, СтаринарXXXIIIXXXIV, 221; И. Поповић, Античко оруће, type IV Ab, 40, cat. 1. 

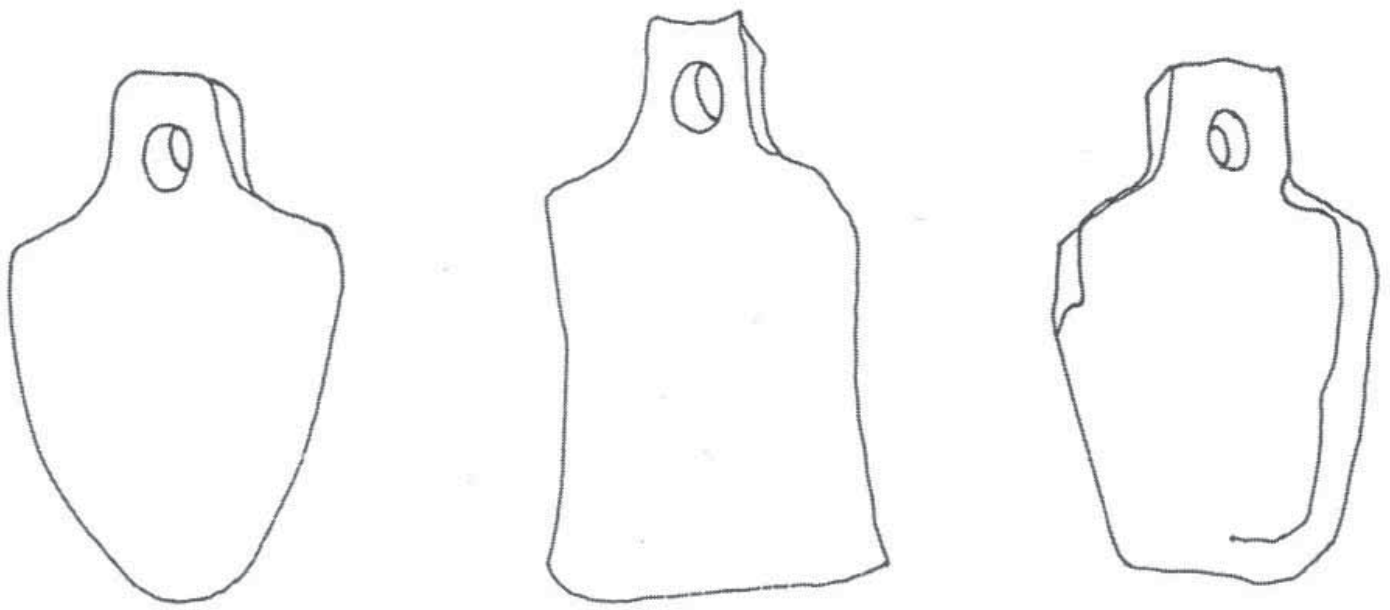

Fig. 2 Different types of hoes from Saldum

(After: G. Jeremić, Saldvm: Roman and Early Byzantine Fortification, Belgrade 2009, fig. 80).

Boljetin (Smorna)

Tool hoard, $4^{\text {th }}$ century

Length: $25.5 \mathrm{~cm}$.

Bibliography: Љ. Зотовић, СтаринарXXXIIIXXXIV, 221; И. Поповић, Античко оруђе, type IV Ab, 41, cat. 2.

Boljetin (Smorna)

Tool hoard, $4^{\text {th }}$ century

Length: $29 \mathrm{~cm}$.

Bibliography: Љ. Зотовић, СтаринарXXXIIIXXXIV, 221; И. Поповић, Античко оруђе, type IV Ab, 41, cat. 3.

From the Danube limes fortifications, there are isolated hoe finds, but also those from hoards. According to the typology by I. Popović, they can be classified as hoe type $B$. Such hoes possess a trapezoid shaped blade, with huge shoulders and a rounded lower blade part. The socket is massive with a hammer-shaped ending.

Variant $B a$ of this hoe type is characterised with an approximately equal blade length and width. Such a type was discovered at the sites of Čezava (Novae), Kostol (Pontes) and Boljetin (Smorna).
Čezava (Novae)

Excavation in 1968, T/1282

$4^{\text {th }}$ century

Length: $19.5 \mathrm{~cm}$.

Bibliography: И. Поповић, Античко оруђе, type

IV Ba, 41, cat. 2 .

Kostol (Pontes)

Excavation in 1980, C/14

$4^{\text {th }}$ century

Length: $20.5 \mathrm{~cm}$.

Bibliography: И. Поповић, Античко оруђе, type IV Ba, 41, cat. 3 .

\section{Boljetin (Smorna)}

Excavation in 1967, inv. nr. 539

Tool hoard, $4^{\text {th }}$ century

Length: $20.5 \mathrm{~cm}$.

Bibliography: Љ. Зотовић, Старинар XXXIIIXXXIV, 221; И. Поповић, Античко оруђе, tyре IV Ba, 41, cat. 6 .

\section{Boljetin (Smorna)}

Excavation in 1968, inv. nr. 864

Tool hoard, $4^{\text {th }}$ century

Length: $21 \mathrm{~cm}$.

Bibliography: Љ. Зотовић, Старинар XXXIIIXXXIV, 221; И. Поповић, Античко оруђе, type IV Ba, 41, cat. 7. 


\begin{tabular}{|c|c|c|c|}
\hline Agricultural tools & Type/variant & Number of tools & Dating \\
\hline \multicolumn{4}{|c|}{ Site ČEZAVA/NOVAE } \\
\hline hoe & IV A/a & 1 & IV century \\
\hline hoe & IV B/a & 1 & IV century \\
\hline \multicolumn{4}{|c|}{ Site SALDUM } \\
\hline ploughshare & XXIII A/a & 1 & IV century \\
\hline ploughshare & XXIII B & 1 & IV century \\
\hline ploughshare & XXIII E & 1 & IV century \\
\hline ploughshare & XXIII C & 1 & IV century \\
\hline hoe & IV A/a & 2 & IV century \\
\hline hoe & IV B/b & 1 & IV century \\
\hline \multicolumn{4}{|c|}{ Site BOLJETIN/SMORNA } \\
\hline ploughshare & XXIII A/a & 3 & IV century \\
\hline ploughshare & $\mathrm{XXIII} \mathrm{A/b}$ & 3 & IV century \\
\hline coulter & XXIV A & 3 & \\
\hline coulter & XXIV B & 1 & \\
\hline hoe & IV Ab & 3 & IV century \\
\hline hoe & IV B/a & 3 & IV century \\
\hline hoe & IV B/b & 3 & IV century \\
\hline hoe & IV B/c & 3 & IV century \\
\hline \multicolumn{4}{|c|}{ Site RAVNA/CAMPSA } \\
\hline ploughshare & XXIII E & 1 & IV century \\
\hline hoe & IV B/b & 1 & IV century \\
\hline \multicolumn{4}{|c|}{ Site KARATAŠ/DIANA } \\
\hline ploughshare & XXIII A/a & 1 & IV-VI century \\
\hline hoe & IV Bc & 1 & IV century \\
\hline \multicolumn{4}{|c|}{ Site KOSTOL/PONTES } \\
\hline ploughshare & XXIII A/a & 1 & IV century \\
\hline ploughshare & XXIII A/d & 1 & IV century \\
\hline ploughshare & XXIII B & 1 & IV-VI century \\
\hline ploughshare & XXIII E & 1 & IV-VI century \\
\hline cleaner hoe & XXVI A & 1 & IV century \\
\hline hoe & IV B/a & 1 & IV century \\
\hline
\end{tabular}

Table 1 The agricultural tools from the Roman sites on the Danubian limes in Upper Moesia. 
Boljetin (Smorna)

Excavation in 1966, inv. nr. 261

$4^{\text {th }}$ century

Length: $26 \mathrm{~cm}$.

Bibliography: Љ. Зотовић, Старинар XXXIIIXXXIV, 221; И. Поповић, Античко оруђе, type IV Ba, 41, cat. 8 .

Variant $B b$ of this type possesses a blade in the shape of a long triangle with a rounded top. It was also discovered in several fortifications along the limes:

\section{Ravna (Campsa)}

Excavation in 1968, field inv. 65

$4^{\text {th }}$ century

Length: $20 \mathrm{~cm}$.

Bibliography: И. Поповић, Античко оруђе, type IV Bb, 103, cat. 2.

\section{Saldum}

Excavation in 1968, field inv. 269

Tool hoard, $4^{\text {th }}$ century

Length: $26 \mathrm{~cm}$.

Bibliography: И. Поповић, Античко оруђе, type IV Bb, 42, cat. 4; G. Jeremić, Saldvm, 165, cat. 490.

Boljetin (Smorna)

Excavation in 1966, inv. nr. 261

$4^{\text {th }}$ century

Length: $25 \mathrm{~cm}$.

Bibliography: Љ. Зотовић, Старинар XXXIII -XXXIV, 221; И. Поповић, Античко оруђе, type IV Bb, 42, cat. 5 .

The third variant of this hoe type possesses a short blade, with an approximately equal length and width.

Karataš (Diana)

Excavation in 1982, C/589

$4^{\text {th }}$ century

Length: $14 \mathrm{~cm}$.
Bibliography: И. Поповић, Античко оруђе, type

IV Bc, 42, cat. 4.

Boljetin (Smorna)

Tool hoard, $4^{\text {th }}$ century

Length: $11 \mathrm{~cm}$

Bibliography: Љ. Зотовић, Старинар XXXIII-

XXXIV, 221; И. Поповић, Античко оруђе, type

IV Bc, 42, cat. 7.

The obtained statistics reveal that along the Danubian limes in Upper Moesia, among Roman soldiers, agriculture played an important role (Table 1). The development and improvement of tools used for cultivating grain, which can be established after analyses of archaeological material, influenced the intensity of agricultural production and increased quantities. At the same time, this indicates the importance of the Danubian limes in the production of grain as the basic food intended for the military stationed in numerous castella along the Danube.

According to inscriptions, it can be concluded that the military administration possessed specific territory, separated from that of a municipal nature. An inscription from the time of Alexander Severus gives testimony that, in 228, in Viminacium, such a military territory (teritorium legionis) was arranged (В. Поповић, 1968: 42). This kind of land ownership played an important role in supplying the army (Zaninović 1985: 63).

Nevertheless, it is not known who owned the land and where the borders of the public land (ager publicus) were, separating it from the legionary owned land (teritorium legionis). During the entire Early Imperial Age, outside these properties, there were certainly important rural communities of autochthonous populations, also practicing farming. This is indicated by a sacrificial altar from Ratiaria, dedicated to the god of herds and pastures, Pali sancto pastorali (Mirković 1968: 138).

While considering Late Roman fortresses along the Danubian limes and the question of 
agricultural producers, one should bear in mind that during this period, apart from major changes in the social life and social status of farmers, there was also a change in the military organisation, which was again reflected in land ownership. From the $4^{\text {th }}$ century onwards, military units along the border, limitanei, living within military camps, were given land that was used as pastures (paludes) (Jones 1973: 629). In 365, according to the law of Valens, for nine months, limitanei were paid in kind, while for three months, they were paid with money. In 406, according to the law of Arcadius, they were fully paid with money (Jones 1973: 630).

The nature of Roman border troops, milites limitanei, during Late Antiquity, is still partly unknown. In 363, for the first time, the name limitanei is mentioned (CTh. XII, I, 56), claiming that these represented troops stationed along the borders of the Empire. According to B. Isaac, one cannot claim that the limitani were just ordinary rural militia, consisting of farmer-soldiers, as was explained in earlier theories, still accepted by many scholars. According to him, these were territorial military units under the command of a dux limitis, whose main role was to control and protect the bordering area of the Empire (Isaak 1988: 146).

The earliest source describing limitanei that till their own land comes from the first half of the $5^{\text {th }}$ century. The law from 423 prohibited anyone, apart from the owner, from tilling land in the vicinity of castellani milites (Jones 1973: 653). The law from 443 prohibited the leasing of land to newcomers, since only the limitanei (milites limitanei), who were previously excused from paying taxes, were allowed to till it (Jones 1973: 654). In such a way, at the beginning of the 5th century, a social layer of land owners was created - the border soldiers - limitanei. Their agricultural activities are attested not only with finds of agricultural tools from the Late Roman layers of the fortifications along the Danubian limes, but also with finds of granaries. In the 1980s, during archaeological research at the military camp in Kostol (Pontes), a large number of oval pits containing burned grain were discovered within the Late Roman layer. Such pits were unearthed in the area of the former principia, already abandoned at this time ${ }^{3}$

Regarding remains of rural settlements with wooden houses, discovered near the military camps along the Danubian limes and dating from the end of the $3^{\text {rd }}$ century to the time of Valentinian I (Petrović, Vasić 1996: 22), as well as other small finds discovered within some of the Late Roman fortresses (Gabričević 1986: 71-91, figs. 23-24) one can speak about the existence of civilian settlements near the military fortifications along the limes in the 4th and at the beginning of the 5th century (Vujović 2012: 29-43).4 It cannot be said with great certainty whether these were settlements of the families of the limitanei or whether rural civilian settlements were established in the vicinity of military camps, in order to supply the neighbouring troops.

3 Information was obtained from Dr. Sofija Petković, senior research fellow of Archaeological Institute from Belgrade, to whom I express my gratitude.

4 This topic was partly addressed by M. Vujović, in his paper about Late Roman helmets from the Danubian limes: M. Vujović, New Contributions on the Late Roman Helmets from Iron Gate, Весник Војног музеја у Београду 39, 2012: 29-43. 


\section{BIBLIOGRAPHY}

Ancient Sources

Cato and Varro, On Agriculture (Cato, Varro, De agricultura), W. D. Hooper, H. B. Ash (trans. by), London-Cambridge-Massachusetts 1967.

Collumela, On Agriculture, (Collumela, De agricultura), vol. I-IV, H. B. Ash (trans. by), London-Cambridge-Massachusetts 1960.

Pliny, Natural History (Plinius, Naturalis historia), H. Rackham (trans. by), London-Cambridge-Massachusetts 1967.

Priscus, Frg. 8, p. 291, 23-26, after: Византијски извори за историју народа Југославије I, (ур.) Г. Острогорски, Београд: $\mathrm{CAH}$.

\section{Contemporary literature}

\section{Gabričević, M. 1986}

Rtkovo - Glamija I, - une forteresse de la basse ероqие, Бердапске свеске III (Cahiers des Portes de Fer), Beograd, Arheološki institut, Nardni muzej, Filozofski fakultet: 71-91.

\section{Isaak, B. 1988}

The Meaning of the Terms Limes and Limitanei in Ancient Sources, JRS LXXVIII: 125-147.

\section{Jeremić, G. 2009.}

Saldvm: Roman and Early Byzantine Fortification, Belgrade: Institute of archaeology.

\section{Jones, A. H. M. 1973}

The Later Roman Empire (AD 284-602): a social, economic and administrative survey, Vol. I, Oxford: Basil Blackwell.

\section{Mirković, M. 1968}

Rimski gradovi na Dunavu u Gornjoj Meziji, Beograd: Arheološko društvo Jugoslavije.

Опра, Љ. 1998

Девет храстова: записи о историји српске метеорологије, Београд: Реп. хидрометеоролошки завод Србије, Музеј науке и технике САНУ.

\section{Petrović, P. and Vasić, M. 1996}

The Roman frontier in Upper Moesia: Archaeological investigations in the Iron Gate area - main results, in: Roman Limes on the Middle and Lower Danube, P. Petrović (ed.), Belgrade, Archaeological institute: 15-26.

\section{Поповић, И. 1988}

Античко оруђе од гвожђа у Србији, Београд: Народни музеј.

\section{Поповић, В. 1968}

Увод у топографију Виминацијума, Старинар XVIII/1967: 29-53.

\section{Vujović, M. 2012}

New Contributions on the Late Roman Helmets from Iron Gate, Весник Војног музеја у Београду 39: 29-43.

\section{Zaninović, M. 1985}

Prata legionis u Kosovu kraj Knina s osvrtom na teritorij Tilurija, Opuscula Archaeologica 10: 6379.

\section{Зотовић, Љ. 1984}

Бољетин (Smorna), римски и рановизантијски логор, Старинар XXXIII-XXXIV: 211-225. 
REZIME

NALAZI RIMSKOG

POLJOPRIVREDNOG ORUĐA

NA DUNAVSKOM LIMESU

U GORNJOJ MEZIJI KAO

POKAZATELJ RAZVOJA

ZEMLJORADNJE NA TERITORIJI

VOJNIH LOGORA

KLJUČNE REČI: POLJOPRIVREDNO ORUĐE, UTVĐENJA NA DUNAVSKOM LIMESU, GORNJA MEZIJA, KASNOANTIČKI PERIOD.

Oruđe korišćeno prilikom obrade poljoprivrednog zemljišta registrovano je u znatnom broju u utvrđenjima uglavnom kasnoantičkog limesa, što ukazuje na promene koje su u ovom periodu nastale u načinu snabdevanja vojske. Većina po- ljoprivrednog oruđa koje potiče iz vojnih logora predstavlja pojedinačne nalaze, mada su registrovane i ostave poljoprivrednog oruđa poput one iz kastruma Boljetin ili Saldum. U radu smo se posebno osvrnuli na oruđe korišćeno za oranje zemlje i pripremu za sadnju žitarica: različiti tipovi raonika, crtala, otikača i motika.

Analizom dostupnog materijala možemo da zaključimo da je na Dunavskom limesu u Gornjoj Meziji poljoprivreda igrala značajnu ulogu. Razvoj i usavršavanje oruđa namenjenog kultivaciji žitarica uticali su, svakako, na intenzitet poljoprivredne proizvodnje i povećanje prinosa. Isto tako, to govori i o značaju koji je oblast Dunavskog limesa imala u proizvodnji žitarica kao osnovne životne namirnice namenjene vojnicima stacioniranim u brojnim kastelima na Dunavu. 